\title{
Species of Euglossa (Glossura) in the Brazilian Atlantic forest, with taxonomic notes on Euglossa stellfeldi Moure (Hymenoptera, Apidae, Euglossina) ${ }^{1}$
}

\author{
Luiz R. R. Faria Jr. ${ }^{2,3}$ \& Gabriel A. R. Melo ${ }^{2,4}$
}

${ }^{1}$ Contribution $n^{\circ} 1648$ of the Departamento de Zoologia, Universidade Federal do Paraná, Brazil.

${ }^{2}$ Laboratório de Biologia Comparada de Hymenoptera, Departamento de Zoologia, Universidade Federal do Paraná. Caixa Postal 19020, 81531-980 Curitiba-PR, Brazil.

${ }^{3}$ Programa de Pós-Graduação em Entomologia, Departamento de Zoologia, UFPR. CNPq fellowship (Brazil). nuno@ufpr.br ${ }^{4} \mathrm{CNPq}$ PQ 2. garmelo@ufpr.br

\begin{abstract}
Species of Euglossa (Glossura) in the Brazilian Atlantic forest, with taxonomic notes on Euglossa stellfeldi Moure (Hymenoptera, Apidae, Euglossina). The species of Euglossa (Glossura) occuring in the Brazilian Atlantic forest were revised and an identification key to males and females is provided. The status of Euglossa annectans Dressler and E. stellfeldi Moure is reevaluated and the latter species is transferred from E. (Glossura) to E. (Glossurella). Here we also synonymize E. carinilabris Dressler under E. stellfeldi. Taxonomic notes are provided and relevant morphological features are illustred. Latitudinal color variation along the Brazilian Atlantic forest, found in two of the species studied here, is also presented and discussed.
\end{abstract}

KEYWORDS. Euglossini; Glossurella; Neotropical; orchid bees.

RESUMO. Espécies de Euglossa (Glossura) da Mata Atlântica, com notas taxonômicas sobre Euglossa stellfeldi Moure (Hymenoptera, Apidae, Euglossina). São revistas as espécies de Euglossa (Glossura) com ocorrência na Floresta Atlântica, incluindo uma chave de identificação para machos e fêmeas. O status de Euglossa annectans Dressler e E. stellfeldi Moure foi reavaliado, com a transferência de E. stellfeldi do subgênero Glossura para Glossurella. É proposta, também, a sinonímia de Euglossa carinilabris Dressler sob Euglossa stellfeldi Moure. Notas taxonômicas e ilustrações de características morfológicas relevantes são apresentadas. Discute-se a variação na cor do integumento ao longo da Floresta Atlântica de duas das espécies aqui estudadas.

PALAVRAS-CHAVE. Euglossini; Glossurella; Neotropical.

The subgenus Glossura was proposed by Cockerell to include the species of Euglossa Latreille with extremely elongated mouthparts, extending far beyond the apex of the abdomen, a biconvex scutellum, labrum longer than wide and with a characteristic keel on the inner surface of the male mid basitarsus (Cockerell 1917; Moure 1969; see Dressler 1978).

Three species of E.(Glossura) are considered widely distributed in the Neotropical region, including the Brazilian Atlantic forest: Euglossa chalybeata Friese, 1925 which occurs in the Amazon Basin and in the Brazilian Atlantic forest (as far south as the Rio de Janeiro state), E. ignita Smith, 1874 occuring in Central America, Amazon Basin and the Brazilian Atlantic forest (also as far south as Rio de Janeiro) and $E$. imperialis Cockerell, 1922 which also occurs in Central America, Amazon Basin and the Brazilian Atlantic forest (as far south as Espírito Santo state). In eastern Brazil, the first two species are restricted to coastal lowland areas covered with Atlantic forest, while the last one also occurrs inland, in areas with semideciduous forest in São Paulo and Minas Gerais states and cerrado in Minas Gerais (Moure 1969; Dressler 1982a; Janzen et al. 1982; Rebêlo \& Garófalo 1997; Bonilla-Gómez 1999; Tonhasca Jr. et al. 2002; Nemésio 2004; Nemésio \& Faria Jr. 2004).

Two additional species of the subgenus Glossura have their distribution restricted to the region considered in this work. Euglossa annectans Dressler, 1982 ranges from the state of Espírito Santo to Santa Catarina (Brazil), besides Paraguay and Argentina (Misiones). Euglossa iopoecila Dressler, 1982 has been considered as restricted to coastal areas in São Paulo and Paraná states (Dressler 1982a; see Peruquetti et al. 1999), although more recently Roubik (2004) proposed that $E$. iopoecila ranges throughout the entire Brazilian Atlantic forest.

Euglossa stellfeldi Moure, as originally proposed, presents the most restricted distribution of the species here considered, occurring only in coastal areas between the states of São Paulo and Santa Catarina (Moure 1947; Dressler 1982a).

It has been hard to provide a safe determination of specimens of these taxa, especially as regards to E. annectans, E. chalybeata, E. iopoecila and E. stellfeldi. When studying material of what he considered E. chalybeata from the Amazon basin and the Atlantic forest, Dressler (1982a) proposed the name E. iopoecila, as a subspecies of E. chalybeata, for the blue color morph found at the southern portion of the Atlantic forest. Recently, Roubik (2004) gave species status to $E$. iopoecila, since he found out consistent structural differences between males of E. chalybeata proper and E. iopoecila. This author also reinterpreted the distribution patterns of these 
taxa: E. chalybeata is restricted to the Amazon Basin and E. iopoecila to the Atlantic forest.

Distinction between $E$. annectans and E. stellfeldi, which have been placed in their own species-group within Glossura (sensu Ramírez et al. 2002; Roubik 2004; see Dressler 1978), is more problematic since they occur in simpatry, and their status as separate species have been questioned recently. Nemésio (2004) proposed the synonymy of $E$. annectans under $E$. stellfeldi, a change followed by Nemésio \& Faria Jr. (2004). Later, Nemésio \& Silveira (2006:320) made the following comment on the status of E. annectans: "in this paper, $E$. annectans is reinstated as a valid species by the first author". In any case, the proper taxonomic treatment of this problem requires the study of the type material of $E$. stellfeldi, which was not done by the authors above.

The development of a sampling methodology focused on males (see Dodson et al. 1969), and the low abundance of euglossine bees in surveys on blooming plants, make it more difficult to determine the identity of the females and associate them correctly with conspecific males. This problem is more relevant here, since the holotype of E. stellfeldi is a female and the holotype of E. annectans, a male (Moure 1947; Dressler 1982a).

The aim of this work is to contribute to the taxonomy of subgenus Glossura occurring in the Brazilian Atlantic forest providing an identification key to the species and reassessing the status of E. stellfeldi and E. annectans. The limits between the subgenera Glossura and Glossurella are discussed and E. stellfeldi is transferred to Glossurella. Also, patterns of latitudinal variation in integument color of these bees along the Brazilian Atlantic forest are presented and discussed.

Morphological terminology adopted here follows Michener (2000) and Roubik (2004). Metasomal terga and sterna are indicated, respectively, as T1 to T7, and S1 to S8. The labels of examined specimens of $E$. stellfeldi were transcribed under the section Material Examined, where one inverted bar symbol (I) indicates the different lines in the label, two inverted bars (II) indicate information on the back side of the label, and the quotation marks indicate different labels associated with one specimen. In the labels, the signs of male and female were transcribed as $\mathrm{M}$ and $\mathrm{F}$, respectively. The density of punctation and intervals between the punctures was based on relative puncture diameter, pd (e.g. <1pd: less than $1 \mathrm{x}$ the puncture diameter between the punctures).

Distribution maps for the studied species was generated in ArcView GIS 3.2, based on locality data from examined specimens deposited at DZUP and with records provided by Wittmann et al. (1988), Rebêlo \& Moure (1995), Neves and Viana (1997), Rebêlo \& Garófalo (1997), Bonilla-Gómez (1999), Peruquetti et al. (1999), Bezerra \& Martins (2001), Tonhasca Jr. et al. (2002), Nemésio (2003), Alvarenga (2004), Nemésio (2004), Nemésio \& Faria Jr. (2004), Souza et al. (2005), as well as on specimens from other institutions examined by one of the authors. Records outside the study area were not included in the maps for those species (E. ignita and E. imperialis) with widespread distribution outside eastern Brazil. In the maps, the Atlantic forest is represented in grey. The Atlantic forest shape files, derived from the ecoregions presented in Olson \& Dinerstein (2002), were obtained at http://worldwildlife.org/ science.

The studied material, including types, belongs to DZUP (Coleção de Entomologia Pe. J. S. Moure, Departamento de Zoologia, Universidade Federal do Paraná), and MHNCI (Museu de História Natural do Capão da Imbuia), both at Curitiba, Brazil.

\section{Comments on the subgenera Glossura and Glossurella}

When Dressler (1978) proposed the current infrageneric classification of Euglossa, he placed E. stellfeldi in a distinct group (the stellfeldi group) apart from other Glossura, which posteriorly also included E. annectans (see Dressler 1982a). Later, Dressler (1982b:131) wrote "I believe that future work may well treat the stellfeldi group and the intersecta and rugilabris groups (these two perhaps together) as distinct subgenera, leaving $E$. (Glossura) a much more homogeneous and natural group". Subsequently, Moure (1989) erected a new subgenus, Glossuropoda, which included the Dressler's groups intersecta and rugilabris and solved this part of the problem within the E. (Glossura). Regarding the stellfeldi group, no other proposal concerning its group placement within $E$. (Glossura) has been advanced.

When comparing E. stellfeldi to species from other subgenera in Euglossa, we found remarkable similarities with E. laevicincta Dressler, 1982, a species placed in E. (Glossurella). Unlike species of E. (Glossura), males of several species of E. (Glossurella), including the two species mentioned above and its type-species (E. bursigera Moure, 1970), present a conspicuous circular depression on the inner surface of the hind tibia. The hair cover of the depressed area varies among species of Glossurella (sensu Ramírez et al. 2002). In E. laevicincta and E. stellfeldi, the depression has a dense hair pile (Fig. 1), while in E. bursigera and related species, the surface is glabrous. In some species of E. (Euglossa) of the analis group (E. cognata Moure, 1970, E. iopyrrha Dressler, 1982 and E. mixta Friese, 1899), the inner surface of the hind tibia also presents a triangular depression covered with denser pubescence. Details of the inner surface of hind tibia have not been considered in previous taxonomic studies and, as we believe, it can provide important features to distinguish species of Euglossa.

Removing E. stellfeldi from E. (Glossura) makes it a more homogeneous group, although the current subgeneric classification for Euglossa remains quite precarious. The limits between the subgenera are not based on phylogenetic analyses and under several aspects are just an arbitrary combination of characters. Only extensive phylogenetic studies could provide robust hypothesis on the position of the species in the different subgenera.

\section{Identification key to species of Euglossa (Glossura) in eastern Brazil, including $\boldsymbol{E}$. (Glossurella) stellfeld $i$ \\ 1- Males: Antennae with eleven flagellomeres; metasoma with}


seven visible segments; midtibia with a conspicuous velvety area on its outer surface; posterior tibia inflated, thick and subtriangular, with a slit surrounded by specialized long hair

Females: Antennae with ten flagellomeres; metasoma with six visible segments; midtibia without a conspicuous velvety area on its outer surface; posterior tibia thin and laminar, with its outer surface largely concave and forming a corbicula . 6

2- Inner surface of the hind tibia with a conspicuous circular depression (Fig. 1); border of hind tibia blade-like along posterior angle; sulcus along the posterior surface of midtibia shallow and weakly indicated on the apical half of the midtibia; epistomal suture forming an obtuse angle in lateral view (Fig. 3) (coastal areas in AL, BA, ES, SP, PR, SC) E. stellfeldi Moure

Inner surface of the hind tibia without a conspicuous circular depression (Fig. 2); border of hind tibia rounded along posterior angle; sulcus along the posterior surface of midtibia deep and strongly indicated on the apical half of midtibia; epistomal suture forming an acute angle in lateral view (Fig. 4), except in E. annectans ... 3

3- Slits of S2 placed laterally on the sclerite, distance between them more than $3 x$ the width of a single slit (Fig. 14); posterior margin of S2 bisinuated; epistomal suture forming an obtuse angle in lateral view; apical tuft of midtibial velvety area distinctly larger than the basal tuft (Fig. 6) (RJ, SP, MG, PR, SC, RS) ..

E. annectans Dressler

Slits of S2 placed close together on the mid portion of the sclerite (Figs. 15-16); posterior margin of S2 distinctly arched; epistomal suture forming an acute angle in lateral view; basal tuft of midtibial velvety area larger than the apical tuft, tufts subequal in size or forming a single elongated tuft (Figs. 7-9) . . .4

4 S2 slits separated by a distance similar to the width of a slit (Fig. 15); metasoma and hind tibia always coppery green; midtibial tufts subequals in size, the apical tuft only slightly larger than the basal tuft (Fig. 8) (BA, ES, $\mathrm{RJ})$. E. ignita Smith

S2 slits large and convergent at mid line of the sternum, almost contacting each other (Fig. 16); metassoma and hind tibia bright metallic green or blue, without strong golden/ brassy reflexes; midtibial basal tuft clearly larger than the apical one or tufts forming a single elongated tuft (Figs. 7,9)

5- Larger and more robust bees (ca. $16 \mathrm{~mm}$ in body length); basal and apical tufts of midtibial velvety area fused (Fig. 7); long hairs on S7 (BA, ES, MG, SP) . E. imperialis Cockerell

Smaller bees (ca. $14 \mathrm{~mm}$ in body length); midtibial tufts clearly separated; basal tuft larger than the apical one
(Fig. 9); short hairs on S7 (coastal areas in BA, ES, RJ, SP, PR, SC) E. iopoecila Dressler

6- Expanded posterior lobe of hind tibia narrower than half of tibia maximum width (Fig. 19); setae of galea well developed (thick and hooked); interocellar area with a distinct protuberance in lateral view; epistomal suture forming an obtuse angle in lateral view (Fig. 3); tongue in repose not exceeding, by far, the apex of metasoma

Expanded posterior lobe of hind tibia broader than half of tibia maximum width; setae of galea, when present, sparse and thin; interocellar area without a distinct protuberance in lateral view; epistomal suture forming a distinct acute angle in lateral view (Fig. 4); tongue in repose exceeding, by far, the apex of metasoma ........... 8

7- Posterior margin of scutellum, in dorsal view, evenly convex; scutellar tuft occupying about two-thirds of scutellum lenght; tegulae moderatelly punctured $(\sim 1$ pd) (RJ, SP, MG, PR, SC, RS) ..... E. annectans Dressler

Posterior margin of scutellum, in dorsal view, slightly grooved medially; scutellar tuft occupying less than two-thirds of scutellum lenght; tegulae densely punctured $(<0.5 \mathrm{pd})$ (coastal areas in AL, BA, ES, SP, PR, SC) ................................................ E. stellfeldi Moure

8- Larger and more robust bees (ca. $16 \mathrm{~mm}$ in body length); surface around scutellar tuft strongly raised, longest setae on posterior border of scutellum about as long as tuft length (BA, ES, MG, SP)

E. imperialis Cockerell

Smaller bees (ca. $14 \mathrm{~mm}$ in body length); surface around scutellar tuft weakly convex, longest setae on posterior border of scutellum longer than tuft length (coastal areas in ES, RJ, SP, PR, SC) .

9- Terga and sterna with strong golden, brassy or coppery reflexes; margin of corbicula with pale yellow bristles only (BA, ES, RJ) .................................... E. ignita Smith

Terga and sterna blue to bluish-violet; margin of corbicula with pale yellow and black bristles

E. iopoecila Dressler

\section{Euglossa (Glossurella) stellfeldi Moure}

(Figures 1, 3, 5, 14, 17-21, 25)

Euglossa stellfeldi Moure, 1947: 11. Holotype female, Brasil: Paraná, Caiobá (MHNCI; examined).

Euglossa (Glossurella) carinilabris Dressler, 1982: 134. Holotype male, Brazil: Bahia, Itabuna (USNM; not examined). New synonymy.

\section{Comments}

The status of E. stellfeldi was reevaluated based on direct study of the female holotype. Although the females of different species of Euglossa are harder to distinguish from one another, we could find stable structural differences between females of 

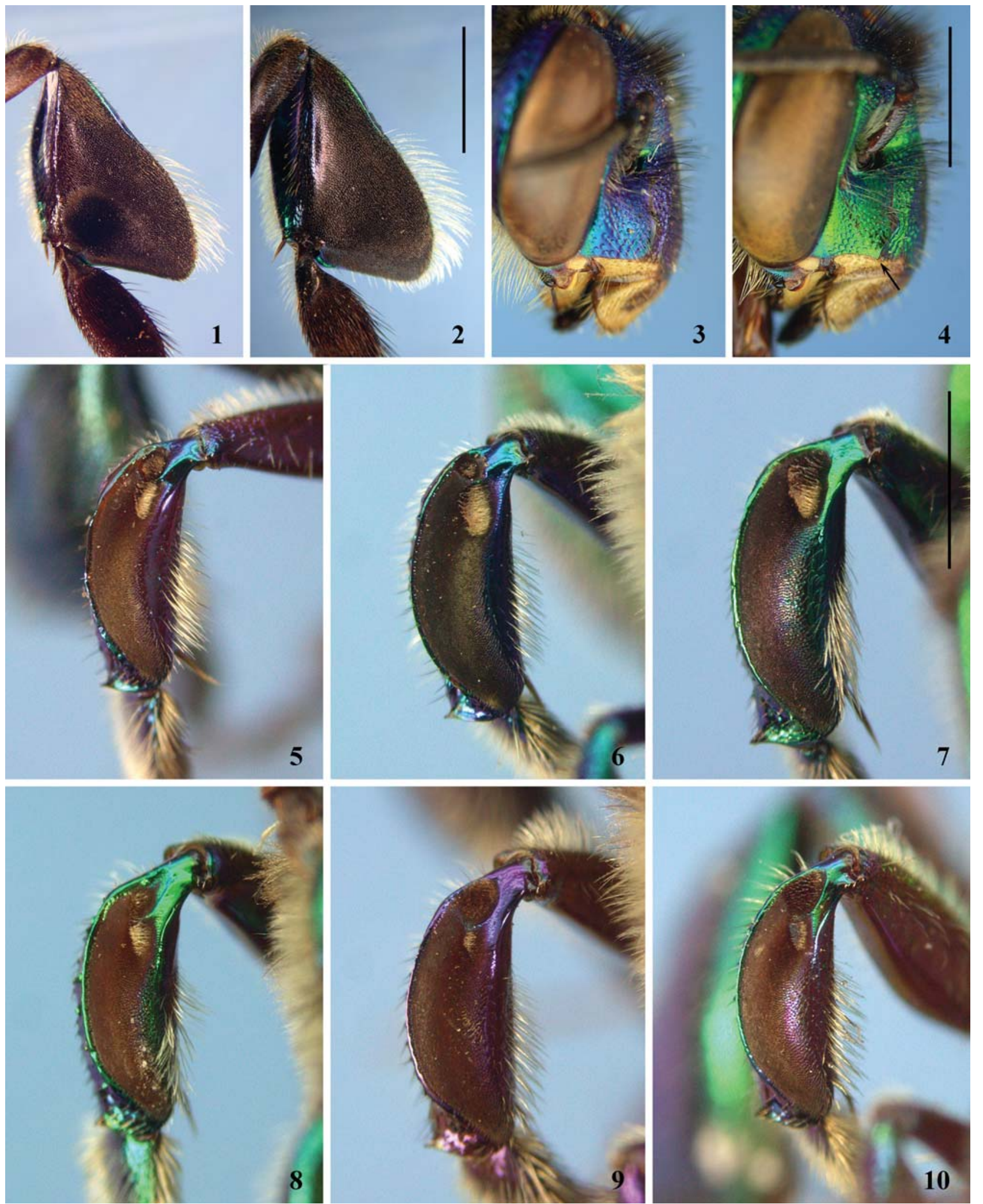

Figs. 1-10. 1, Inner surface of hind tibia of male of E. sttelfeldi (from Cananéia, São Paulo). 2, Same, E. annectans (from Florianópolis, Santa Catarina). Left scale bar $(=2.0 \mathrm{~mm})$ applies to Figs. 1 and 2. 3, Head, in lateral view, showing detail of epistomal suture of female of E. stellfeldi (from Alexandra, Paraná). 4, Same, E. imperialis; arrow pointing to acute angle formed by the epistomal suture (from Conceição da Barra, Espírito Santo). Right scale bar $(=2.0 \mathrm{~mm})$ applies to Figs. 3 and $4.5-10$. Outer surface of male midtibia, showing the hair tufts of the velvety area; scale bar $(=1.5 \mathrm{~mm})$ on Fig. 7 applies to all figures. 5, E. stellfeldi (from Cananéia, São Paulo). 6, E. annectans (from Florianópolis, Santa Catarina). 7, E. imperialis (from Conceição da Barra, Espírito Santo). 8, E. ignita (from Conceição da Barra, Espírito Santo). 9, E. iopoecila (from Alexandra, Paraná). 10, E. chalybeata (from Belém, Pará). 
E. stellfeldi and other congeneric species. It is superficially similar to females of $E$. annectans, the main differences between them being the punctation of the tegula, which is very dense $(<0,5 \mathrm{pd})$ in E. stellfeldi, and the shape of scutelum, which is slightly grooved in the latter species. Females of these two species also differ in the contour of the apical border of the hind tibia (with a distinctly deeper emargination in E. stellfeldi) and in the clypeal punctures (coarser and sparser in $E$. stellfeldi).

Males of E. stellfeldi differ from sympatric males of $E$. (Glossura) in the Atlantic forest by the shape of midtibial tufts and by the presence of a distinct depression, with differentiated hairs, in the inner surface of hind tibia (Fig. 1). This species can be distinguished from males of Euglossa s.str. by tongue length and shape of midtibial tufts and from other sympatric E. (Glossurella) (E. augaspis Dressler, 1982, E. crassipunctata Moure, 1968 and E. sapphirina Moure, 1968) by the shape of midtibial tufts, larger body size and by the hairy depression on inner surface of hind tibia.

As discussed above, E. stellfeldi is transferred to $E$. (Glossurella) considering the several features it shares with other species of this subgenus. Regarding its position whithin the subgenus, E. stellfeldi is very similar to E. laevicincta Dressler, both being large Glossurella (ca. 12mm), and their males having two tufts in midtibia and bidentate mandibles. Studying additional species of E. (Glossurella) we noticed that $E$. carinilabris Dressler is identical to $E$. stellfeldi, except for slight differences in integument color. Therefore, we here synonymyze $E$. carinilabris under $E$. stellfeldi. Although not part of the type series, the examined material of E. carinilabris has the same label data as part of the type series, including Dressler's manuscript species number associated to the holotype (see below 'Additional Examined Material')

The available locality records indicate that $E$. stellfeldi seems to be restricted to coastal areas in eastern Brazil, including mountain slopes in Espírito Santo (Fig. 25). The records of E. stellfeldi presented by Nemésio (2004) and also Nemésio and Faria Jr. (2004) for interior areas represent misidentifications of E. annectans (see below), a common species in semideciduous forests (see Rebêlo \& Moure 1995; Nemésio \& Silveira 2006).

A single nest of $E$. stellfeldi, found within a bamboo cavity, was described by Laroca (1991). Since all previously known nests of Glossurella are aerial (Dodson 1966; Young 1985; Eberhard 1988; see Ramírez et al. 2002; Cameron 2004), this is the first cavity-nesting species in Glossurella, although other species in this subgenus are likely to nest in cavities as well.

\section{Type Material Examined}

Holotype female (MHNCI), "Est. Paranál Caiobál M. Paranaensell C. Stellfeld 26-VI-1943" "Holótipo" "255" "Euglossa F\ stellfeldi\P. Moure det.\1945"; 1 female (MHNCI), "Est. Paranál Matinho\M. Paranaensell J. Bigarella\ 28-III-1945" "Paratypus" "254" "Euglossa F\ stellfeldi\ P. Moure det.\1946"; 1 female (DZUP), "Est. Paraná Matinhol\ Hatschbach\ II- 1941" "Paratypus" "Euglossa F\ stellfeldi〉 n sp.\P. Moure det 1946"; 1 male (MHNCI), "Paraná II-1946\Caiobál R. Lange - Leg" "164" "Allotypus" "Euglossa M\stellfeldi\ n.sp.\P. Moure det.\1946"; 1 male (DZUP), "Est. Paranál Matinholl Hatschbach
II-1941" "Paratypus" "stellfeldi" "Euglossa\ stellfeldi\ m.\ Det. J.S. Moure 1956".

\section{Additional Examined Material (DZUP)}

BRAZIL: Alagoas. 1 male, "Maceió- Alagoas- Brasill 22-I-2006, Rios, P.A.F. leg." "Serra da Saudinha, Usina Cachoeira, em Canistrum alagoanum, (Flor) Hora: 8:25"; 1 male, same except “...29-I-2006..." and "...Hora: 8:41"; 1 female, same except “...Hora: 8:20"; Bahia. 1 female, "Ilhéus - Bahia\ Brasil 16-VII-1965\S. Laroca, leg"; 1 male, "Brazil: Bahia:\Itabuna\6.XI.1968\ R.L. Dressler 1207" "II eugenol" "Holotypus M\Glossurella\ carinilabris $\backslash$ Pe. J.S. Moure 1968"; 2 males, same except "Paratypus $M \backslash$ Glossurella\ carinilabris $\backslash$ Pe. J.S. Moure 1968". Espírito Santo. 1 male, "Depto. Zooll UF - Paraná" "Sta. Tereza - V. Alegre ES-BR\13-17/III/67\ C. \& C.T. Elias leg.”. Paraná. 4 males, "Depto Zool\ UF - Paraná" "Alexandra - PR\25.I.1969\Pe. J.S. Moure"; 8 males, "Alexandral PR - Brasil 01-II-69\ Moure Laroca"; 1 male, "Depto Zool\ UF - Paraná" "Alexandra - PR\ Brasil - 10/10/ 70\ Moure \& Mielke"; 1 female, "Alexandra - PR\ Brasil\ 06.VIII.1983। S. Laroca \&\ M.C. Almeida" "em flores de Jacarandal puberula"; 1 male, "Depto Zool\ UF - Paraná" "Antonina - PR\30.I.1969\ Moure \& Laroca"; 3 males, "eug" "Antonina - PR\ 02.II.1969\ Moure \& Laroca"; 1 male, "Antonina\ PR - Brasil\ 30-2-1969\ Pe. J.S. Mourel cineol" "E. (Glossura) M\ stellfeldi\ Moure $\backslash$ Pe. J. S. Moure 1969"; 1 male, "Antonina\ PR - 01-II-86\ Pe. J.S. Moure leg." "E. (Glossura) stellfeldi M\Pe. J.S. Moure 1986"; 1 male, "Antonina - PR\ (Res. Biol. Sapitanduva)\Brasil 25.III.87\ Exc. PG/ Entom. - DZUP"; 2 males, "Caiobá - Pr.\ 1 a 2/II/1964\ R. Lange leg." "E. (Glossura)\ stellfeldi M \ Pe. J.S. Moure 1986"; 1 male, same except “...1 a 8/II/1964...”; 1 male, "Ilha do Mel - PR\ Praia Grande\ 01/01/89\ Renato Dutra col."; 1 female, same except "...03/09/89..."; 1 male, same except “...16/10/ 88..."; 1 male, "Brasil, Paranál 4Km SE de Morretes $\backslash 25^{\circ} 30$ '33,5"S,। 48 48'30,5", 64m 23. iii.2004, G. Melo"; 1 male "DZUP\027138"

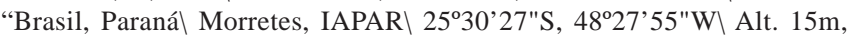
08.iv.2006,\A. Martins, Eugenol."; 1 male, same except "DZUP\ 027141 " “...V. Mattozo, L.R.R. Faria Jr. ...”; 1 male, same except “DZUP\027142"; 1 male, same except "DZUP\027149” “...V. Mattozo..."; 1 male, same except "DZUP\ 027151" “...G. Weiss..."; 9 males, "Atami, Paranaguá, PR\ Pe. J. S. Moure\ Mielke leg. 14.II.94"; 2 males, "Tagaçaba\ PR - Brasil\ 9-III-1969 J.S. Moure". Santa Catarina. 1 female, "Corupál S. Catarina Brasil\ Fevereiro 1958\A. Maller"; 1 female, same except “...Janeiro 1959..."; 1 male, "eug" "Joinville SC\9-II-1969\S. Laroca" "Euglossa M\stellfeldi\ Moure\ Pe. J.S. Moure 1992"; 1 male, "Depto. Zool.I UF - Paraná" "JoinvilleSC\10/VI/1972\ Mers leg.". São Paulo. 1 male, "Brasil, São Paulol Cananéia. Ilha dol Cardoso. 02-03.x\2004.\ S. Augusto leg."; 1 male, "IBUSP, São Paulo, SP\ Juréia Brasil 15.7.1982\ Col: F.R.N.K.\ P39.A2-12:56" "luciael USP + 2 parat. M\ 6"; 1 male, same except “..22.2.1983 ...Eug.-A5-9:50” "E. (Glossura) \luciae M\n. sp.\Pe. J.S. Moure det. 1983"; 1 male, same except "...30.8.1983...P34.-A2-11:30" "luciaell 4"; 1 female, same except “...22.9.1983...P39.-A2-13:40" "E. (Glossura) \luciae F\ n. sp.\ Pe. J. S. Moure det. 1983"; 1 female, "S. Sebastião - SP\ Brasil 1 1945 A. Barbiellini" "E. (Glossura) \annectans\ Pe. J. S. Moure 1964"; 1 female, "Praia do Barrol São Sebastião\SP Brasil\ I-1944 Barbiellini" "\\M 270". Unknown locality. 1 female, "E. (Glossura)\ iopoecila M\Dressler, 82\ Det. J.S. Moure 1993".

\section{Euglossa (Glossura) annectans Dressler}

(Figures 2, 6, 22)

Euglossa annectans Dressler, 1982: 127. Holotype male, Brasil: Guanabara, Floresta da Tijuca (USNM; not examined).

\section{Comments}

Nemésio (2004) synonymized $E$. annectans under $E$. stellfeldi without justifying his taxonomic decision, and this synonymy was also followed by Nemésio and Faria Jr. (2004). The study of type material of these two species reveals, 

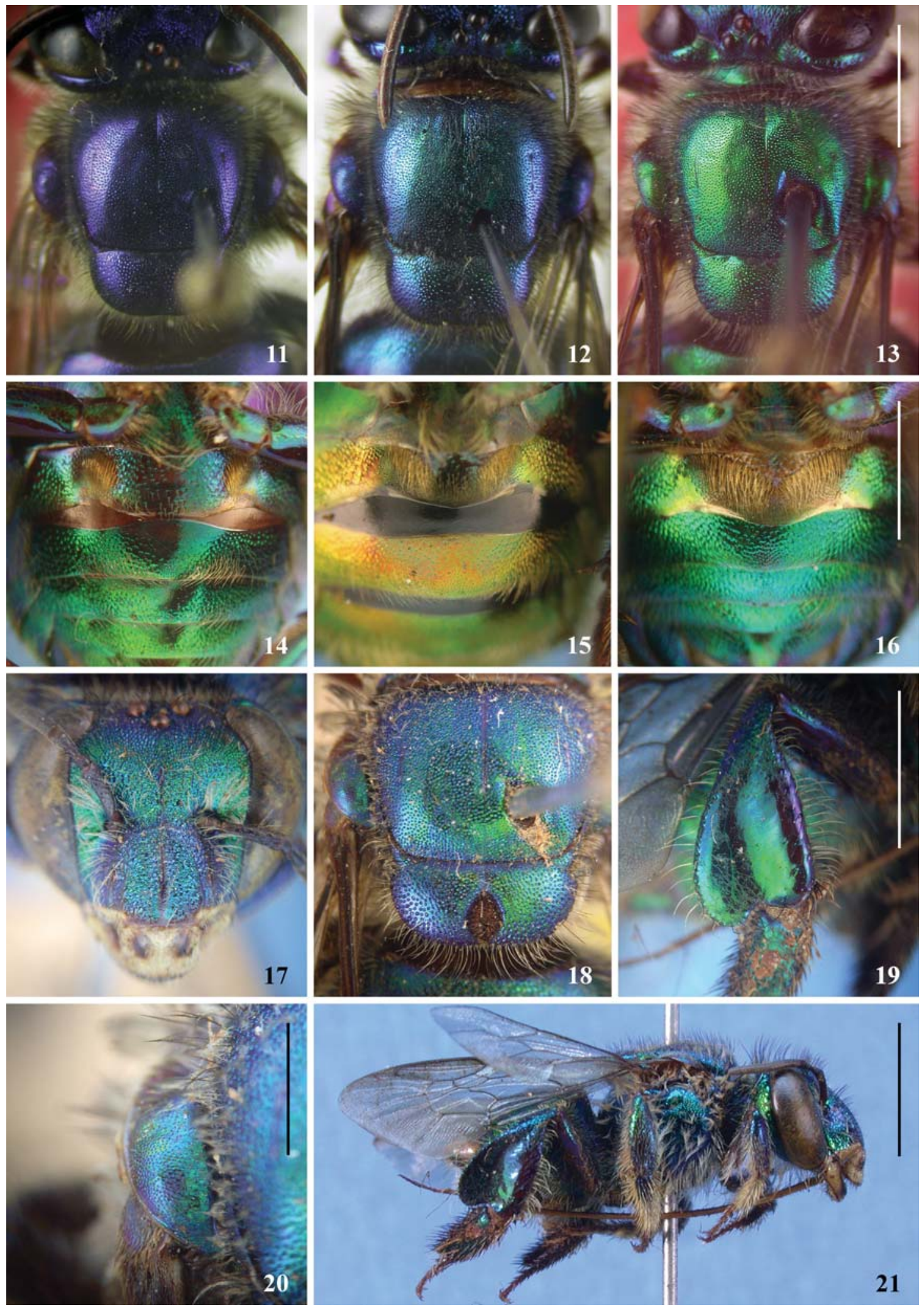

Figs. 11-21. 11-13, Male mesosoma, in dorsal view, illustrating variation in the integument color of E. iopoecila; scale bar = 2.5 mm. 11, Specimen from Alexandra, Paraná, southern Brazil. 12, Specimen from Cananéia, São Paulo, southeastern Brazil. 13, Specimen from Conceição da Barra, Espírito Santo, eastern Brazil. 14-16, Male metasoma, in ventral view, showing the S2 hair slits; scale bar $=2 \mathrm{~mm}$. 14, E. stellfeldi (from Cananéia, São Paulo). 15, E. ignita (from Conceição da Barra, Espírito Santo). 16, E. iopoecila (from Cananéia, São Paulo). 17-21, Female holotype of E. stellfeldi. 17, Head, in frontal view. 18, Mesosoma, in dorsal view. 19, Hind tibia. 20, Tegula, in dorsal view, showing punctation. 21. Lateral overview. Upper scale bar $(=4.0 \mathrm{~mm})$ applies to Figs. $17-19$. Scale bar $(=1.0 \mathrm{~mm})$ in Fig. 20 applies only to it. Scale bar $(=4.0 \mathrm{~mm})$ in Fig. 21 applies only to it. 
however, that they constitute very distinct species. Dressler (1982a) considered that $E$. annectans formed with $E$. stellfeld $i$ a separate group in Glossura and this position was followed in subsequent checklists for Euglossina (Ramírez et al. 2002; Roubik \& Hanson 2004) and taxonomic works (e.g. Rebêlo \& Moure 1995; Roubik 2004).

Transfer of E. stellfeldi to E. (Glossurella) leaves $E$. annectans in an isolated position in the subgenus Glossura. It differs in several features from species of the piliventris group: i) angle of epistomal suture, in lateral view, not acute; ii) apical knob, on the inner surface of hind tibia (near spur), small (this knob is large in the piliventris group); iii) specialized seta, in the lower border of female hind tibia (between corbicula and basitarsus), well developed (indistinct in females of the piliventris group).

Available locality records indicate that $E$. annectans is restricted to the southern portion of the Atlantic forest in Brazil, including the inland forests of the Parana basin, south to Misiones, in Argentina (Fig. 22). Within its geographical range, E. annectans can be found in coastal areas (from Rio de Janeiro to Santa Catarina), where it is sympatric with E. stellfeldi, and also in inland areas of southeastern Brazil, both in semideciduous forests (Rebêlo \& Moure 1995; Rebêlo \& Garófalo 1997) and savannas (Nemésio \& Faria Jr. 2004).

\section{Type Material Examined}

Paratypes deposited at DZUP are not labeled as such, but based on Dressler (1982a), they can be easily recognized: 1 male, "BRAZIL: GB. Flor- $\backslash$ esta de Tijuca\ 6 I 1966\ R.L.Dressler 444" "Euglossa M annectans $\backslash$ Dressler\ Pe J.S. Moure 1986"; 1 male, "BRAZIL: GB. Flor\ esta de Tijuca\ 9 I 1966\ R.L.Dressler 444" "Euglossa M\annectans\ Dressler\ Pe. J.S. Moure 1986"; 1 female, "BRAZIL: GB. Flor- $\backslash$ esta de Tijuca\ 8 I 1966\ R.L.Dressler 444" "Euglossa F\ annectans\Pe. J.S. Moure 1967". There are several other specimens labeled as paratypes at DZUP, but these were not indicated in Dressler's paper.

Material Examined from southeastern Brazil and Argentina ARGENTINA. Misiones. Puerto Iguazú (7 males). BRAZIL. Rio de Janeiro. Rio de Janeiro (18 males and 9 females). São Paulo. Brotas (1 male), Campinas (1 male and 1 female), Jundiaí (1 male), Luís Antônio (1 male) and Teodoro Sampaio (1 male). Paraná. Alexandra (17 males), Antonina (22 males), Morretes (6 males and 1 female), Tapejara (1 male) and Xambrê (1 female). Santa Catarina. Florianópolis ( 7 males and 9 females), Joinville (3 males), São Francisco do Sul (2 males) and São Martinho (2 males). Rio Grande do Sul: Tenente Portela (4 males).

\section{Euglossa (Glossura) ignita Smith} (Figures 8, 15, 22)

Euglossa ignita Smith, 1874: 444. Holotype male, Jamaica (BMNH; not examined).

Euglossa ignita var. chlorosoma Cockerell, 1918: 688. Holotype female, Guyana: Bartica District (AMNH; not examined).

\section{Comments}

We compared specimens of E. ignita from Espírito Santo and Bahia, in eastern Brazil, with those from Central America and northern South America and did not find any relevant structural differences among them. Roubik (2004) mentions that E. ignita ranges from west Amazonia to southern Mexico, overlooking many reports on the presence of this species in the Brazilian Atlantic forest (Neves \& Viana 1997; BonillaGómez 1999; Bezerra \& Martins 2001; Tonhasca Jr. et al. 2002) (Fig. 22). Regarding the metasomal color of E. ignita, we observed that in specimens from Bahia, the golden reflexes in terga and sterna are distinctly stronger than in specimens from Espírito Santo.

\section{Material Examined from eastern Brazil}

Bahia. Cumuruxatiba (1 male) and Prado (10 males). Espírito Santo. Conceição da Barra (21 males) and Linhares (3 males and 2 females).

\section{Euglossa (Glossura) imperialis Cockerell (Figures 4, 7, 23)}

Euglossa (Glossura) piliventris imperialis Cockerell, 1922: 6. Holotype female, Panamá: Rio Trinidad (USNM; not examined).

\section{Comments}

This is the largest species of Glossura found in eastern Brazil and presents the largest geographical distribution of all species in the subgenus (Rebêlo \& Moure 1995; Ramírez et al. 2002; Roubik 2004). Individuals from Central America, Amazon Basin and Atlantic forest are very similar, indicating that its populations form a continuum. Occurrence of E. imperialis in savanna areas of Minas Gerais (Nemésio \& Faria Jr. 2004) also suggests connection between Amazonian and Atlantic populations through central Brazil (Fig. 23), as discussed by Rebêlo and Moure (1995).

Integument color variation was also observed in individuals from the Atlantic forest. Specimens from eastern Brazil (Bahia) presented stronger golden and coppery reflexes than those from southern areas of its distribution (Espírito Santo), which are normally entirely bright green.

\section{Material Examined from eastern Brazil}

Bahia. Cumuruxatiba (1 male), Itabuna (2 males), Ilhéus (1 female), Prado (48 males) and Porto Seguro (5 males). Espírito Santo. Conceição da Barra (199 males and 1 female) and Linhares (2 males). São Paulo. Pedregulho (1 male).

\section{Euglossa (Glossura) iopoecila Dressler} (Figures 9, 11-13, 16, 24)

Euglossa chalybeata iopoecila Dressler, 1982: 126. Holotype male, Brasil: Paraná, Alexandra (USNM; not examined).

\section{Comments}

When describing E. iopoecila, Dressler (1982a) gave great importance to differences in integument color. He proposed this name, as a subspecies of $E$. chalybeata, for the blue color morph found at the southern portion of the Atlantic forest, while the green northern population was treated as typical $E$. chalybeata. Comparison of specimens from the type localities of both species (E. chalybeata: Belém, Pará, Brazil; E. iopoecila: Alexandra, Paraná, Brazil) supported the status proposed by Roubik (2004). Besides differences in the shape of the tufts of the midtibial velvety area (Figs. 9-10), additional 


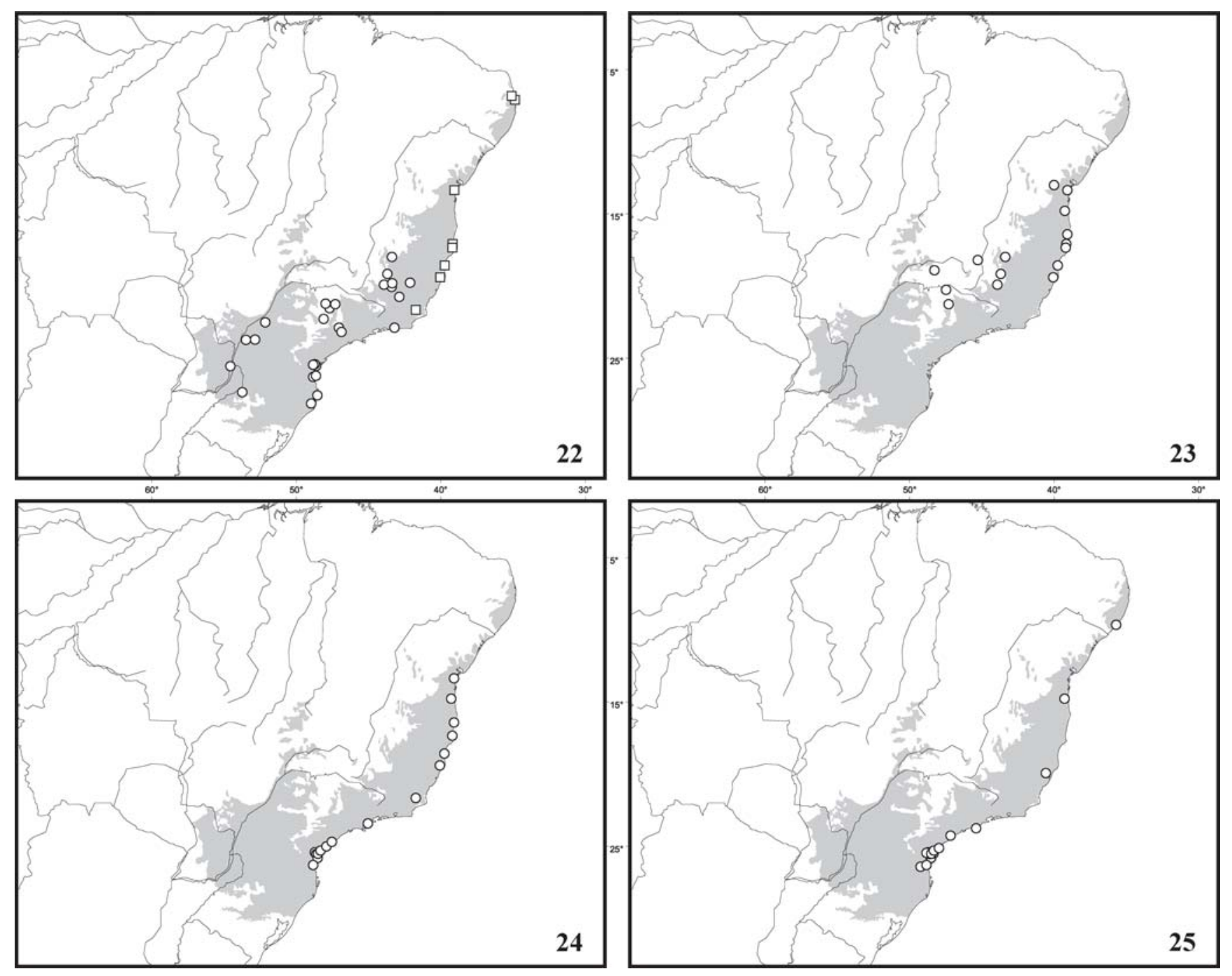

Figs. 22-25. Distribution maps. 22, Euglossa annectans (circles) and E. ignita (squares). 23, E. imperialis. 24, E. iopoecila. 25, E. stellfeldi. Records outside eastern Brazil were not included in the maps for E. ignita and E. imperialis. The Atlantic forest is represented in grey.

features distinguish these two species: i) E. iopoecila presents sparser punctures on the posterior margin of the scutellum (near the scutellar depression); ii) in E. chalybeata, punctures on $\mathrm{T} 4$ and $\mathrm{T} 5$ reaches the posterior margin of these sclerites, while in E. iopoecila the posterior margin of T4 and T5 are smooth; iii) E. iopoecila presents denser plumose hairs on the mesepisternum than E. chalybeata.

The different color morphs found in the Atlantic forest, which varies from completely bluish-violet in southern Brazil (Paraná and Santa Catarina) to mostly green in eastern Brazil (Espírito Santo and Bahia), are here interpreted as the result of a latitudinal gradient of variation (see below). This color variation from dark blue to green seems to be gradual, since we examined specimens from Ubatuba, in São Paulo, and northern Rio de Janeiro, that present an intermediate coloration (Figs. 11-13). It is remarkable that these intermediate colored bees come from areas in the middle of the species range.

Along its range, males of E. iopoecila also vary in the density of punctation in the disc of T2: individuals from Santa Catarina, Paraná, São Paulo and some of Espírito Santo present a dense punctation $(<1 \mathrm{pd})$, while other specimens from Espírito Santo and Bahia present a moderate punctation $(>1 \mathrm{pd})$. Presence of a white spot on the anterior surface of the scape also varies, completely lacking in some individuals or occupying up to half of the anterior surface of the scape.

Only two females were available for study (DZUP), one labeled "Paranaguá, Paranál 16.iv.1995\Moure\ Olaf H.H. Mielke leg." "Euglossa F\mandibularis\Friese, 1899\ Det. J.S. Moure 1996" and the other, part of the type series of $E$. stellfeldi, "Est. Paranál Matinhol\ J. Bigarella\28.III.1945" "Paratypus" "stellfeldi" "Euglossal stellfeldi\ Det. J.S. Moure 1956". These two females have a predominantly blue to bluishviolet color, as males from this region. In the northern portion of its distribution, females of E. iopoecila will likely have a predominantly green color. These specimens are probably very similar to females of E. ignita, perhaps differing only for lacking 
strong golden, brassy or coppery reflexes in the metasoma. Besides color, we could not find structural differences to separate E. ignita from E. iopoecila.

Regarding its distribution pattern, current data indicate that $E$. iopoecila, similarly to $E$. stellfeldi, is restricted to coastal areas in eastern Brazil (from Bahia to Santa Catarina) (Fig. 24).

\section{Type Material Examined}

One male at DZUP, although it cannot be considered a paratype according to the original description (Dressler, 1982a), has the same label data as the type series: "Brazil: PR.। Alexandral 8.XII.1968 M R.L.Dressler" "Cineol".

\section{Material Examined from eastern Brazil}

Bahia. Itabuna (1 male), Prado (4 males) and Porto Seguro (4 males). Espírito Santo. Conceição da Barra (79 males) and Linhares (18 males). São Paulo. Cananéia (1 male), Iguape (1 male) and Ubatuba (3 males). Paraná. Alexandra (40 males), Antonina (26 males), Matinhos (1 female), Paranaguá (1 female) and Tagaçaba (7 males). Santa Catarina. Joinville (1 male).

\section{Latitudinal color variation along the Brazilian Atlantic forest}

Coloring in nature mostly comes from the inherent colors of materials, but it sometimes has a purely physical origin, such as diffraction or interference of light. The latter, called structural color or iridescence (Kinoshita \& Yoshioka 2005), is relatively common among Neotropical bees, including those of the genus Euglossa.

In these groups of bees, a diverse range of color hues is exhibited by different species, and these differences are widely used in their taxonomy (e.g. Dressler 1978). In Euglossa, intraspecific color variation has not been well documented, although small differences are usually mentioned in the descriptions (e.g. Rebêlo \& Moure 1995).

For two of the species studied here, E. iopoecila and $E$. stellfeldi, we found a latitudinal gradient of color variation: individuals from the northern portion of the distribution range are green (with golden/ coppery reflexes), while individuals from the southern portion are greenish blue (E. stellfeldi) or bluish violet (E. iopoecila). In both cases, specimens from the middle portion of the distribution present an intermediate color.

Also, Nemésio (2006) recently described a species, $E$. anodorhynchi, from southern Brazil, which has a conspicuous blue integument. Except for its blue color, this new form is structurally almost identical to E. townsendi Cockerell, 1904 a green species occurring further north, from southeastern Brazil to Mexico. Similarly to the two cases studied here, it might be possible that $E$. anodorhynchi represent only a color variation within a more widely distributed taxon.

Except for E. annectans, all species of Euglossa found in the southern portion of the Atlantic forest (Paraná and Santa Catarina), E. anodorhynchi, E. iopoecila, E. mandibularis Friese, E. stellfeldi, and an undescribed form of the analis group, have a predominantly blue or greenish blue body color. This apparent tendency to become greenish-blue or dark blue in southeastern Brazil must be taken into consideration in taxonomic works, avoiding misidentifications of species based only in differences of integument color.
Color polymorphisms in adult organisms of many taxa are often adaptive in the context of sexual selection or predation (e.g. Abbott \& Svensson 2005) and may be associated to the insect physiology, as in water balance (e.g. Appel \& Tanley 1999). The color variation described here in Euglossa is an interesting feature to be focused in future behavioral and physiological studies.

Acknowledgments. CNPq for providing a scolarship to the first author; to Tereza Cristina C. Margarido and Solange Regina Malkowiski (MHNCI) for lending us the type series of E. stellfeldi; and Instituto Ambiental do Paraná for the collecting permit (\#55/05) which allowed us to collect some of the bees included in this study.

\section{REFERENCES}

Abbott, J. \& E. I. Svensson. 2005. Phenotypic and genetic variation in emergence and development time of a trimorphic damselfly. Journal of Evolutionary Biology 18: 1464-1470.

Alvarenga, P. E. F. 2004. Riqueza de Euglossini (Hymenoptera: Apidae) em áreas de cerrado no município de Uberlândia, MG, Senior Thesis, Universidade Federal de Uberlândia, Uberlândia, $26 \mathrm{pp}$.

Appel, A. G. \& M. J. Tanley. 1999. Water composition and loss by body color and form mutants of the german cockroach (Dictyoptera: Blattellidae). Comparative Biochemistry and Physiology Part A 122: 415-420.

Bezerra, C. P. \& C. F. Martins. 2001. Diversidade de Euglossinae (Hymenoptera, Apidae) em dois fragmentos de Mata Atlântica localizados na região urbana de João Pessoa, Paraíba, Brasil. Revista Brasileira de Zoologia 18: 823-835.

Bonilla-Gomez, M. A. 1999. Caracterização da Estrutura Espaçotemporal da Comunidade de Abelhas Euglossinas (Hymenoptera, Apidae) na Hiléia Bahiana, Ph.D. Thesis, Universidade Estadual de Campinas, Campinas, xii $+153 p$.

Bonilla-Gómez, M. A. \& G. Nates-Parra. 1992. Abejas Euglossinas de Colombia (Hymenoptera: Apidae) I. Claves Ilustradas. Caldasia 17: $149-172$

Cameron, S. A. 2004. Phylogeny and biology of neotropical orchid bees. Annual Review of Entomology 49: 377-404.

Cockerell, T. D. A. 1917. Some euglossine bees. The Canadian Entomologist 49: 144-146.

Dodson, C. H. 1966. Ethology of some bees of the tribe Euglossini (Hymenoptera: Apidae). Journal of the Kansas Entomological Society 39: 607-629.

Dodson, C. H.; R. L. Dressler; H. G. Hills; R. M. Adams \& N. H. Williams. 1969. Biologically active compounds in orchid fragrances. Science 164: 1243-1249.

Dressler, R. L. 1978. An infrageneric classification of Euglossa, with notes on some features of special taxonomic importance (Hymenoptera: Apidae). Revista de Biologia Tropical 26: 187198.

Dressler, R. L. 1982a. New species of Euglossa. II. (Hymenoptera, Apidae). Revista de Biologia Tropical 30: 121-129.

Dressler, R. L. 1982b. New species of Euglossa. III. The bursigera species group (Hymenoptera: Apidae). Revista de Biologia Tropical 30: 131-140.

Eberhard, W. G. 1988. Group nesting in two species of Euglossa bees (Hymenoptera: Apidae). Journal of the Kansas Entomological Society 61: 406-411.

Janzen, D. H.; M. L. DeVries; M. L. Higgins \& L. S. Kimsey. 1982. Seasonal and site variation in Costa Rican euglossine bees in lowland deciduous and evergreen forest. Ecology 63: 66-74.

Kimsey, L. S. \& R. L. Dressler. 1986. Synonymic species list of Euglossini. Systematic Entomology 12: 63-72.

Kinoshita, S. \& S. Yoshioka. 2005. Structural colors in nature: the role 
of regularity and irregularity in the structure. ChemPhysChem 6: $1442-1459$.

Laroca, S. 1991. Euglossa stellfeldi: arquitetura do ninho e coexistência com Pseudocentron apicipennis em uma mesma cavidade (Hymenoptera, Apoidea). Acta Biológica Paranaense 20: $103-$ 108.

Michener, C. D. 2000. The Bees of the World. Baltimore, John Hopkins University Press, xiv +913 p.

Moure, J. S. 1947. Novos agrupamentos genéricos e algumas espécies novas de abelhas sulamericanas. Publicações Avulsas do Museu Paranaense 3: $1-37$.

Moure, J. S. 1967. A checklist of the known euglossine bees. Atas do Simpósio sobre a Biota Amazônica (Zool.) 5: 395-415.

Moure, J. S. 1969. The Central American species of Euglossa subgenus Glossura Cockerell, 1917 (Hymenoptera, Apidae). Revista de Biologia Tropical 15: 227-247.

Moure, J. S. 1989. Glossuropoda, novo subgênero de Euglossa, e duas espécies novas da Amazônia, do mesmo subgênero (Apidae, Hymenoptera). Memórias do Instituto Oswaldo Cruz 84: $387-$ 389.

Nemésio, A. 2003. Preliminarly sampling of Euglossina (Hymenoptera: Apidae: Apini) of Reserva Particular do Patrimônio Natural "Feliciano Miguel Abdala", Caratinga, Minas Gerais, southeastern Brazil. Lundiana 4: 121-124.

Nemésio, A. 2004. Composição e riqueza em espécies e abundância de males de Euglossina (Hymenoptera: Apidae) de remanescentes florestais de Mata Atlântica no estado de Minas Gerais, MSc. Thesis, Universidade Federal de Minas Gerais, Belo Horizonte, vi $+154 \mathrm{p}$.

Nemésio, A. 2006. Euglossa anodorhynchi sp. n. (Hymenoptera: Apidae), a new orchid bee from southern Brazil. Neotropical Entomology 35: 206-209.

Nemésio, A. \& L. R. R. Faria Jr. 2004. First assessment of the orchidbee fauna (Hymenoptera: Apidae) at Parque Estadual do Rio Preto, a cerrado area in southeastern Brazil. Lundiana 5: 113-117.

Nemésio, A. \& F. A. Silveira. 2006. Edge effects on the orchid-bee fauna (Hymenoptera: Apidae) at a large remnant of Atlantic rain forest in southeastern Brazil. Neotropical Entomology 35: 313323.
Neves, E. L. \& B. F. Viana. 1997. Inventário da fauna de Euglossinae (Hymenoptera: Apidae) do baixo sul da Bahia, Brasil. Revista Brasileira de Zoologia 14: 831-837.

Olson, D. M. \& E. Dinerstein. 2002. The Global 200: Priority ecoregions for global conservation. Annals of the Missouri Botanical Garden 89: 199-224.

Peruquetti, R. C.; L. A. O. Campos; C. D. P. Coelho; C. V. M Abrantes \& L. C. Lisboa. 1999. Abelhas Euglossini (Apidae) de áreas de Mata Atlântica: abundância, riqueza e aspectos biológicos. Revista Brasileira de Zoologia 16: 101-118.

Ramirez, S.; R. L. Dressler \& M. Ospina. 2002. Abejas euglossinas (Hymenoptera, Apidae) de la región Neotropical: lista de especies con nota sobre su biologia. Biota Colombiana 3: 7-118.

Rebêlo, J. M. M. \& J. S. Moure. 1995. As espécies de Euglossa Latreille do nordeste de São Paulo (Apidae, Euglossinae). Revista Brasileira de Zoologia 12: 445-466.

Rebêlo, J. M. M. \& C. A. Garófalo. 1997. Comunidades de machos de Euglossinae (Hymenoptera, Apidae) em matas semidecíduas do nordeste do estado de São Paulo. Anais da Sociedade Entomológica do Brasil 26: 787-799.

Roubik, D. W. 2004. Sibling species of Glossura and Glossuropoda in the Amazon Region (Hymenoptera: Apidae: Euglossini). Journal of the Kansas Entomological Society 77: 235-253.

Roubik, D. W. \& P. E. Hanson. 2004. Orchid bees: biology and field guide. San Jose, CR Inbio, 370p.

Souza, A. K. P.; M. I. M. Hernandez \& C. F. Martins. 2005. Riqueza, abundância e diversidade de Euglossina (Hymenoptera, Apidae) em três áreas da Reserva Biológica Guaribas, Paraíba, Brasil. Revista Brasileira de Zoologia 22: 320-325.

Tonhasca Jr., A.; J. L. Blackmer \& G. S. Albuquerque. 2002. Abundance and diversity of euglossine bees in the fragmented landscape of the Brazilian Atlantic Forest. Biotropica 34: 416-422.

Young, A. M. 1985. Notes on the nest structure and emergence of Euglossa turbinifex Dressler (Hymenoptera: Apidae: Bombinae: Euglossini) in Costa Rica. Journal of the Kansas Entomological Society 58: $538-543$.

Wittmann D.; M. Hoffmann \& E. Scholz. 1988. Southern distributional limits of euglossine bees in Brazil linked to habitats of the Atlanticand Subtropical Rain Forest (Hymenoptera: Apidae: Euglossini). Entomologia Generalis 14: 53-60. 